\title{
Russian Diplomatic Espionage in Italy
}

\section{The Biot Affair and International Law}

\author{
Caterina Milo \\ Department of Law, Economics, Management and Quantitative Methods, \\ University of Sannio, Piazza Guerrazzi, Italy \\ caterina.milo@unisannio.it
}

\begin{abstract}
After uncovering Russian espionage activities on Italian territory, Italy expelled two Russian diplomats allegedly involved in such activities. The Italian decision, as well as the Russian response, offer a classic example of States' reaction to acts of non-violent espionage. This comment offers a legal assessment of the events that unfolded in March 2021 and takes into account the implications, in matters concerning espionage, of declarations of persona non grata, diplomatic immunity and, generally, customary international law.
\end{abstract}

\section{Keywords}

espionage - Russia - Italy - diplomatic immunities - persona non grata - Vienna Convention on Diplomatic Relations - functional immunity

In March 2021 Italy arrested an Italian Navy official on charges of providing highly classified documents to Russian agents, and expelled two Russian diplomats allegedly implicated in the espionage. This comment aims to provide an international law assessment of these facts. In order to do so, it first offers an overview of the events, as gathered from the numerous press reports of both Italian and foreign news outlets. It then looks at three key aspects of this incident: firstly, Italy and Russia's recourse to declarations of persona non grata; secondly, the scope of the two Russian diplomats' immunity from Italian jurisdiction with respect to their undercover activities; and thirdly, the issue 
whether Russia's acts of espionage may amount to violations of general international law.

Before delving into the legal assessment, a brief summary of the facts is necessary. On 30 March 2021, the Italian police stopped two individuals in a car park in Rome. The two were an Italian Navy official, Capt. Walter Biot, and Dmitrij Ostroukhov, a military attaché at the Russian embassy in Rome. When the Italian authorities intervened, the Navy official had handed over a memory card containing 181 photos all classified as confidential - of which nine were "highly confidential" and 47 secret documents from NATO - in exchange for 5000 euros. ${ }^{1}$ Capt. Biot was arrested and is still in custody awaiting trial, while Ostroukhov's status was reported as "under consideration" 2 due to his diplomatic rank. Indeed, military attachés enjoy diplomatic immunity and privileges as outlined in Article 7 of the 1961 Vienna Convention on Diplomatic Relations ("VCDR"). ${ }^{3}$

On 31 March, the Italian foreign minister, Luigi Di Maio, announced through his social media accounts that:

On the occasion of the summoning of the Russian ambassador to Italy to the Ministry of Foreign Affairs and International Cooperation, we conveyed to him the firm protest of the Italian government and notified the immediate expulsion of the two Russian officials involved in this extremely grave affair. I thank our intelligence services and all of the State's apparatus that every day work for the security of our country. ${ }^{4}$

On the same day Di Maio appeared before the Italian Parliament's third committee "Foreign and European Community Affairs", where he reported that the

1 The news was widely reported by Italian newspapers. See ex multis Sarzanini, "Spionaggio, ufficiale di Marina italiano arrestato: «Ha dato documenti Nato ai russi»", Corriere della Sera, 31 March 2021, available at: <https://www.corriere.it/esteri/21_marzo_31/spionaggioarrestato-militare-italiano-avrebbe-passato-documenti-segreti-un-ufficiale-russo-7азаза7291f2-11eb-b997-507c83c4e681.shtml>; Di Feo, "'Ufficiale italiano spiava per i russi'. Due fermi a Roma. Di Maio: 'Atto ostile di estrema gravità", la Repubblica, 31 March 2021, available at: $<$ https://www.repubblica.it/esteri/2021/03/31/news/ufficiale_italiano_spiava_per_i_russi_ due_fermi_a_roma-294475219/?ref=tgpr>; Mangani, "Ufficiale arrestato: «Ha venduto segreti a Mosca». Roma frena sullo Sputnik”, Il Messaggero, 1 April 2021, available at: <https://www. ilmessaggero.it/italia/ufficiale_arrestato_spia_russia_walter_biot_vaccino_sputnik_ultima_ ora_1_aprile_2021-5869508.html >.

2 Italian Carabinieri, "Roma. Documenti a militare russo, fermato ufficiale italiano per spionaggio", 31 March 2021, available at: <http://www.carabinieri.it/cittadino/informazioni/ news/2021/o3/31/newo-20210331092700-1178407>.

3 Vienna Convention on Diplomatic Relations, 18 April 1961, entered into force 24 April 1964.

4 Di Maio (@luigidimaio), 31 March 2021, available at: <https://twitter.com/luigidimaio/ status/1377204417599004674>. All translations from Italian sources are the author's. 
Ambassador of the Russian Federation, Sergey Razov, had been summoned to the Ministry to "forcefully convey [Italy's] firm protest and notify the expulsion of two Russian officials accredited at the embassy in Rome". He also qualified the Russian actions as unacceptable and "a hostile act of extreme gravity". Di Maio however added that communication between the two parties was necessary in order to prevent an escalation "that nobody wants". ${ }^{5}$

Italian newspapers reported that Razov tried to negotiate with the Italian government in order to limit the expulsion only to the Russian diplomat caught with Capt. Biot. ${ }^{6}$ Nevertheless, Aleksej Nemudrov, another military attaché at the Russian embassy in Rome, suspected of being Ostroukhov's direct superior, was expelled as well. The two left Italy on 1 April with a commercial flight. ${ }^{7}$ Razov commented on the events, declaring that both the incident and the Italian decision to declare the two Russian officials personae non gratae caused deep regret. He however pointed out that Russia hoped that the incident would not negatively affect the good relations between the two countries. ${ }^{8}$ This came among a number of mixed reactions from the Russian authorities. Leonid Slutskiy, chairman of the Russian Parliament's international affairs committee, declared that the expulsion had no grounds and that the gesture would leave a negative imprint on the Russian-Italian dialogue. ${ }^{9}$ However, a Kremlin spokesman confirmed that Russia still wished to maintain good relations with Italy. ${ }^{10}$ On 26 April 2021, Russia expelled a defence and naval attaché in the Italian Embassy in Moscow, Curzio Pacifici. ${ }^{11}$ The retaliatory expulsion

5 Senato della Repubblica, "Comunicazioni del Ministro degli affari esteri", 31 March 2021, available at: $<$ https://webtv.senato.it/Leg18/4621?video_evento=177101>.

6 Castelletti, Nigro, "Subito espulsi due diplomatici russi. L'Italia aspetta la contromossa di Putin", la Repubblica, 31 March 2021, available at: <https://rep.repubblica.it/pwa/ generale/2021/03/31/news/subito_espulsi_due_diplomatici_russi_l_italia_aspetta_la_ contromossa_di_putin-29458608o/>.

7 Bonini et al., "L'errore di Aleksej che ha bruciato la talpa nella Difesa", la Repubblica, 1 April 2021, available at: <https://rep.repubblica.it/pwa/generale/2021/04/o1/news/_ errore_di_aleksej_che_ha_bruciato_la_talpa_nella_difesa-294728788/>.

8 "L'ambasciatore Razov a Rainews24: 'Roma mantenga la linea del dialogo"', Rai News, 2 April 2021, available at: <http://www.rainews.it/dl/rainews/media/Razov-Roma-mantenga-lalinea-del-dialogo-e993eafb-5od3-4c57-a180-o179b1188oog.html>.

9 “Слуцкий предупредил о последствиях высылки россиян из Италии", Interfax, 31 March 2021, available at: <https://www.interfax.ru/russia/758820 >.

10 Messia, Chernova, "Italy expels two Russian officials over espionage case", CNN, $3_{11}$ March 2021, available at: <https://edition.cnn.com/2021/03/31/europe/italy-russia-espionageexpulsion-intl/index.html>.

11 Italy's Ministry of Foreign Affairs and International Cooperation, "Nota Federazione Russa", 26 April 2021, available at: <https://www.esteri.it/mae/it/sala_stampa/archivionotizie/ comunicati/nota-federazione-russa.html\#h $>$. 
of an Italian diplomat occurred relatively late, among a series of expulsions and rising tensions between Russia and many Western countries. ${ }^{12}$ However, as is common among friendly countries, the Russian authorities expelled an individual whose posting was about to expire. ${ }^{13}$

By expelling the two Russian agents, Italy followed standard practice. Indeed, while the term commonly used is "expulsion", it is only a "convenient shorthand to denote use of the procedure in Article 9" 14 of the VCDR. This Article provides that the receiving State may at any time notify the sending State that a member of a diplomatic mission is persona non grata. As a result of this declaration the sending State is obliged to recall its agent. If this does not happen or if the sending State terminates the agent's functions, the receiving State will be able to consider the agent as a private citizen deprived of diplomatic status. ${ }^{15}$ Article 9 stipulates that the sending State should carry out its obligation within a "reasonable period", but does not offer a specific timeframe. While 48 hours are generally regarded as the minimum reasonable time, ${ }^{16}$ sometimes only 24 hours are given..$^{17}$ In this case, an Italian newspaper reported that the two Russian agents were only given 24 hours ${ }^{18}$ and the same amount of time was given by Russia to the Italian diplomat expelled in retaliation. ${ }^{19}$

12 See "Russia expels Czech diplomats over spying row", ввс News, 20 April 2021, available at: <https://www.bbc.com/news/world-europe-56796324>; Foy, Hopkins, "Russia expels Bulgarian diplomats as tensions with west intensify", Financial Times, 20 April 2021, available at: <https://www.ft.com/content/52daaab3-6bba-4523-a5b4-85b51abf61be>; Castelletti, “Russia, Putin avverte l'Occidente: 'Mai superare la linea rossa', la Repubblica, 21 April 2021, available at: <https://rep.repubblica.it/pwa/generale/2021/04/21/news/ putin_avverte_l_occidente_mai_superare_la_linea_rossa_-297483312/>.

"Mosca espelle addetto navale aggiunto all'Ambasciata d'Italia: «Una ritorsione»", Corriere della Sera, 26 April 2021, available at: <https://www.corriere.it/cronache/21_aprile_26/ mosca-espelle-addetto-navale-aggiunto-all-ambasciata-d-italia-una-ritorsione-b7bae288a67f-11eb-b37e-o7dee681b819.shtml>.

14 Denza, Diplomatic Law. Commentary on the Vienna Convention on Diplomatic Relations, 4 th ed., Oxford, 2016, p. 66.

15 D'aspremont, "Persona non grata", Max Planck Encyclopedia of Public International Law, 2009, para. 12; United States Diplomatic and Consular Staff in Tehran (United States of America v. Iran), Judgment of 24 May 1980, ICJ Reports, 1980, p. 3 ff., para. 86.

17 D'ASPREMONT, cit. supra note 15, para. 13.

18 Caprara, "Spionaggio e arresto Walter Biot, la strettoia di Mosca: reagire, smorzare o prender tempo?", Corriere della Sera, 31 March 2021, available at: <https://www.corriere.it/esteri/21_ marzo_31/spionaggio-arresto-biot-strettoia-mosca-reagire-smorzare-o-prender-tempoo5a2a1ae-925b-11eb-b997-507c83c4e681.shtml>.

19 Corriere della Sera, 26 April 2021, cit. supra note 13. 
Article 9 VCDR is the cornerstone of the self-contained regime that is diplomatic law. The International Court of Justice in the Tehran Hostages case stated that:

The rules of diplomatic law, in short, constitute a self-contained régime which, on the one hand, lays down the receiving State's obligations regarding the facilities, privileges and immunities to be accorded to diplomatic missions and, on the other, foresees their possible abuse by members of the mission and specifies the means at the disposal of the receiving State to counter any such abuse. ${ }^{20}$

Although the text of Article 9 does not require that the expelled diplomats are suspected of illicit or improper activities or that the receiving State offers any explanation for the expulsion, ${ }^{21}$ the declaration of persona non grata is a typical remedy for violations of Article $41 \mathrm{VCDR}$, which provides that all diplomats must respect the laws and regulations of the receiving State and abstain to interfere in the internal affairs of that State. For this reason, the use of Article 9 for cases of espionage is extremely common. ${ }^{22}$ Exemplary is the UK practice, where it has been expressly provided that "[a]s a general rule espionage and incitement to or advocacy of violence require an immediate declaration of persona non grata". ${ }^{23}$ In a similar case of 2001, the United States declared four Russian agents personae non gratae after the arrest of Robert Hanssen, a FBI agent accused of spying for the Russians. In that case, Russia symmetrically expelled four US diplomats. ${ }^{24}$

Thus far the only reactions by Italy and Russia have been declarations of persona non grata, but espionage activities carried out by diplomatic agents give rise to at least two other fundamental points: the range of the agents' privileges and immunities and the possibility for a State to invoke a violation of international law.

As mentioned, Ostroukhov and Nemudrov were both military attachés and therefore enjoyed diplomatic privileges and immunities. It is for this reason that, while the Italian authorities immediately arrested Capt. Biot,

\footnotetext{
20 United States Diplomatic and Consular Staff in Tehran, cit. supra note 15, para. 86

21 DENZA, cit. supra note 14, p. 68.

22 FOAKES, DENZA, "The Diplomatic Mission, The Corps, Breach of Rrelations, and Protection of Interests", in RoberTs (ed.), Satow's Diplomatic Practice, 7th ed., Oxford, 2016, p. 153 ff., p. $158 \mathrm{ff}$.

23 The text is reported ibid., p. 165.

24 U.S. Department of State, "Expulsion of Russian Intelligence Officers", 22 March 2001, available at: $<$ https://20o1-20og.state.gov/r/pa/prs/ps/2001/157o.htm >.
} 
Ostroukhov's status was duly considered and no further arrests were made. Italy complied with the letter of Article $29 \mathrm{VCDR}$, which provides that " $[\mathrm{t}] \mathrm{he}$ person of a diplomatic agent shall be inviolable. He shall not be liable to any form of arrest or detention". No exceptions to the rule of the personal inviolability of the diplomatic agent are admitted save "on the basis of self-defence or of an overriding duty to protect human life". 25

While personal inviolability does not raise any major issues, the question of immunity from criminal prosecution is more nuanced. Indeed, even though espionage is a crime in almost all national legal systems, the criminal courts of the receiving State cannot, as a rule, judge a diplomatic agent suspected of acts of such nature. Under Article $31 \mathrm{VCDR}$, diplomatic agents enjoy immunity from the criminal jurisdiction of the receiving State. This immunity is absolute, since the three exceptions provided by the same article ${ }^{26}$ only apply to the civil and administrative jurisdiction of the State. ${ }^{27}$ During their posting, agents benefit from personal and functional immunity. The former applies to all actions of the diplomat, regardless of their nature, but ceases to apply once the functions of a person have come to an end. Functional immunity, on the other hand, protects the agent even after their posting has ended, but only "with respect to acts performed by such a person in the exercise of his functions as a member of the mission". ${ }^{28}$ Consequently, a State seeking to prosecute a foreign spy that is still a diplomatic agent on its territory will inevitably be barred by personal immunity. This was the case for the Russian agents until they were expelled. After their expulsion, when their posting came to an end, a prosecution would however still be barred by functional immunity if acts of espionage were to be qualified as within the agents' official functions.

In order to assess whether espionage may qualify as an official function of a diplomat, it should firstly be noted that the main functions of a diplomatic mission are outlined in Article 3(1) VCDR and include the protection of the interests of the sending State and the gathering of information on the

25 DENZA, cit. supra note 14, p. 223.

26 Art. 31(1) VCDR: “(a) A real action relating to private immovable property situated in the territory of the receiving State, unless he holds it on behalf of the sending State for the purposes of the mission; (b) An action relating to succession in which the diplomatic agent is involved as executor, administrator, heir or legatee as a private person and not on behalf of the sending State; (c) An action relating to any professional or commercial activity exercised by the diplomatic agent in the receiving State outside his official functions".

27 DuQuet, "Immunities of Diplomatic and Consular Personnel", in RUYs and ANGELET (eds), The Cambridge Handbook of Immunities and International Law, Cambridge, 2019, p. 411 ff., p. 417 .

28 Art. 39.2 VCDR. 
receiving State "by all lawful means". While this article provides guidance, the list included therein is non-exhaustive. The actual definition of the diplomatic mission's activities is left to the States involved ${ }^{29}$ and the final scope of the official functions will depend on the consent of the receiving State. ${ }^{30}$ Against this backdrop, some States have expressly qualified acts of espionage as not being included in official diplomatic functions. ${ }^{31}$ As for the Italian practice, in the Abu Omar case, ${ }^{32}$ the Italian Corte di Cassazione dismissed a claim of consular immunity by two US agents accused of cooperating in the kidnapping of Abu Omar, an Egyptian asylee residing in Italy and allegedly tortured by the Egyptian authorities. The Court stated that while the Vienna Convention on Consular Relations granted functional immunity to consular agents for actions "performed in the exercise of consular functions", ${ }^{33}$ that did not mean that such agents could undertake any action as long as it was in the interest of the sending State. ${ }^{34}$ The Court thus underlined the essential role of the consent of the receiving State. ${ }^{35}$ In the following Medero case $^{36}$ - concerning the same facts but with regard to diplomatic agents - the same Court reaffirmed its position by stating that the agents did not enjoy functional immunity since they did not act in the exercise of their diplomatic functions but rather as "high-ranking officials of the CIA in Italy". ${ }^{37}$

The main implication of the reasoning of the Italian courts in Abu Omar and Medero is that the qualification of the acts as official ones is up to the

29 It is not a simple matter of attribution to a State. However, in this sense see Federal Constitutional Court (Germany), Former Syrian Ambassador to the German Democratic Republic, Case 2 BvR 1516/96, 115 ILR 595.

VAN ALEBEEK, "Functional Immunity of State Officials", in RUYS and ANGELET (eds), The Cambridge Handbook of Immunities and International Law, Cambridge, 2019, p. 496 ff., p. 508; SHI, "Diplomatic immunity ratione materiae, immunity ratione materiae of state officials, and state immunity: A comparative analysis", Leiden Journal of International Law, 2021, p. 45 ff., p. 5 o.

31 Declaration of the Direction du droit international public du Département Politique Fédéral, reported in CAFLISCH, "La pratique suisse en matière de droit international public 2005", Swiss review of international and European law, 2005, p. 605 ff., p. 629.

32 Corte di Cassazione (Sez. V penale), Abu Omar case, General Prosecutor at the Court of Appeals of Milan v Adler and ors, 29 November 2012, no. 46340.

33 Vienna Convention on Consular Relations, 24 April 1963, entered into force 19 March 1967, Art. 43 .

34 Abu Omar case, cit. supra note 32, para. 23.4.

35 VAN ALEBEEK, cit. supra note 30, p. 507.

36 Corte di Cassazione (Sez. V penale), In the matter of criminal proceedings against Medero and ors, Medero and ors v Nasr (aka Abu Omar) and Ghali, 25 September 2014, no. 39788.

37 Ibid., para. 2.2 . 
receiving State's courts ${ }^{38}$ and it will probably be made on a case-by-case basis. Even though, as has been shown, Italy would not shy away from prosecuting individuals enjoying functional immunity for acts of espionage, the case at hand is fairly different from the precedents analyzed. In this case, the actions of the Russian officials were ingrained within their diplomatic cover and it would arguably be hard to prove, as was done in Medero, that they only acted as intelligence officials without the technical support of their diplomatic mission.

The matter would be different if the secret agents were not diplomatic agents as well. It is generally regarded that under customary international law only high-ranking officials of the State enjoy personal immunity from criminal jurisdiction. ${ }^{39}$ As for functional immunity, again the Italian Corte di Cassazione in Abu Omar held that functional immunity of individuals other than Heads of States and Ministers of Foreign Affairs is only offered by specific treaty regimes and there is not sufficient practice to recognize a customary rule granting immunity from criminal jurisdiction in respect of any actions of any State officials. ${ }^{40}$ This view is contrasted by a majority of scholarship ${ }^{41}$ and, recently, by the Enrica Lexie decision, where the arbitral tribunal found that "[i]mmunity ratione materiae is enjoyed by State officials in general, irrespective of their position in the hierarchy of the State". ${ }^{42}$ However, regardless of the preferred view, there is general agreement that secret agents are not entitled to immunity. Special Rapporteur Escobar Hernández even proposed to include a "territorial tort exception" in the Draft Articles on Immunity of State officials from foreign criminal jurisdiction. ${ }^{43}$ While the proposal was ultimately not

38 VAN ALEBEEK, cit. supra note 30, p. 507.

39 See Draft Articles 3 and 4, ESCOBAR HERnÁNDEZ, Eighth report on immunity of State officials from foreign criminal jurisdiction, UN Doc. A/CN.4/739, 202O, p. 20.

40 Abu Omar case, cit. supra note 32, para. 23.7; AMoroso, "Sull'(in)esistenza di un regime generale in materia di immunità funzionale degli organi stranieri", Giurisprudenza italiana, August/September 2013, p. $1900 \mathrm{ff}$. This view was outlined in DE SENA, Diritto internazionale e immunità funzionale degli organi statali, Milano, 1996. See also FRU LLI, Immunità e crimini internazionali: l'esercizio della giurisdizione penale e civile nei confronti degli organi statali sospettati di gravi crimini internazionali, Torino, 2007.

41 See on the point Kolodkin, Second report on immunity of State officials from foreign criminal jurisdiction, UN Doc. A/CN.4/631, YILC, 2010, Vol. II, Part One, p. 395 ff., para. 21: "There is to all appearances also agreement in the doctrine on the question of the category of persons enjoying immunity ratione materiae: all State officials are meant, irrespective of their position within the structure of the organs of State power". See also VAN ALEBEEK, cit. supra note 3 o.

42 The "Enrica Lexie" Incident (Italy v. India), PCA Case No. 2015-28, Award, 21 May 2020, para. 848 .

43 See the proposal for Draft Article 7, ESCOBAR HERNÁNDEZ, Fifth report on immunity of State officials from foreign criminal jurisdiction, UN Doc. A/CN.4/701, 2016, p. 95. 
welcomed, secret agents are not usually granted functional immunity ${ }^{44}$ and the International Law Commission has clarified that espionage, among other acts, does not give rise to functional immunity. ${ }^{45}$

Moving to the second point, the use of declarations under Article 9 does not preclude the receiving State from taking countermeasures for violations of the VCDR, as long as they do not affect diplomatic personnel. ${ }^{46}$ The lingering question is therefore whether Italy might claim a violation of international law for these acts of (peacetime) espionage. The matter is all but settled. While espionage might lead to violations of treaty law, international law does not provide a general prohibition of it. ${ }^{47}$ According to some, the lack of an express prohibition implicitly admits its legality. ${ }^{48}$ This view is based on the Lotus ${ }^{49}$ doctrine according to which, as long as there is no explicit prohibition, States are free to adopt the principles which they regard "as best and most suitable"..$^{0}$ On the other end, many have tried to infer a prohibition of espionage from the principle of non-interference. ${ }^{51}$ While this prohibition may apply in some extreme cases, it is doubtful that all intelligence-gathering operations may meet the threshold of unlawful interference. The main issue is that practice and opinio of States are extremely ambiguous on the topic: espionage is at the same time vastly practiced and publicly condemned. ${ }^{2}$ While the question remains

44 Conforti, iovane, Diritto internazionale, 12th ed., Naples, 2021, p. 276. On the topic see: Ronzitti, "The immunity of State organs - A reply to Pisillo Mazzeschi", Questions of International Law, 2015, p. $59 \mathrm{ff}$.

45 International Law Commission, Report on the work of the sixty-ninth session, UN Doc. A/72/10, YILC, 2017, chapter VII, para. 24.

46 Simma, PUlkows Ki, "Of Planets and the Universe: Self-contained Regimes in International Law”, European Journal of International Law, 2006, p. 483 ff., p. 513; HERDE GEN, "The Abuse of Diplomatic Privileges and Countermeasures not Covered by the Vienna Convention on Diplomatic Relations", Heidelberg Journal of International Law, 1986, p. 734 ff., pp. 746-747. SCHALlER, "Spies”, Max Planck Encyclopedia of Public International Law, 2015, para. 2.

48 For a recollection of the different views see LUBIN, "The Liberty to Spy", Harvard International Law Journal, 2020, p. 185 ff.; PUN, "Rethinking Espionage in the Modern Era", Chicago Journal of International Law, 2017, p. 353 ff.

49 S.S. Lotus (France v. Turkey), Judgment of 7 September 1927, PCIJ Reports, Series A, No. 10, p. $1 \mathrm{ff}$.

5 O Ibid., para. 19.

$5^{1}$ WRIGHT, "Espionage and the Doctrine of Non-Intervention in Internal Affairs" in STANGER (ed), Essays on Espionage and International Law, Columbus, 1962, p. 3 ff.; BEIM, "Enforcing a Prohibition on International Espionage", Chicago Journal of International Law, 2018, p. $647 \mathrm{ff}$.

52 LUbin, cit. supra note 48, p. 225; CheSterman, "The Spy Who Came in From the Cold War: Intelligence and International Law", Michigan Journal of International Law, 2006, p. $1071 \mathrm{ff}$., p. 1072. 
open, it might be better to refer - as some have proposed ${ }^{53}$ - to a liberty to spy, subject to limitations in extreme cases but left to a grey area of international relations.

In conclusion, both Italy and Russia seem to have acted well within the usual diplomatic practice. Considering the friendly relations between the two countries, it is almost certain that the matter will end with the declarations of persona non grata. As has been shown, the facts of this case are significantly different from the Abu Omar and Medero cases and it would be hard to prove that the two Russian agents did not enjoy the functional immunity connected to their diplomatic cover. Moreover, the nature of the actions is different. Nonviolent acts of espionage, however serious, will often be silently left to the diplomatic relations of the countries involved. It would therefore be a hard task to prove that Russia somehow violated general international law by committing acts of peacetime espionage on Italian territory.

53 LUBIN, cit. supra note 48. 